\title{
$\checkmark$ Research Square \\ What is the Molecular Basis of Aroma in \\ Biriyanicheera - A Tropical Aromatic Rice Genotype
}

\section{VEERABHADRASWAMY M}

Kerala Agricultural University College of Horticulture

P SINDHUMOLE ( $\nabla$ sindhumole.p@kau.in )

Kerala Agricultural University College of Horticulture https://orcid.org/0000-0001-9971-3454

\section{DEEPU MATHEW}

Kerala Agricultural University College of Horticulture

\section{R SHYLAJA}

Kerala Agricultural University College of Horticulture

\section{JIJI JOSEPH}

Kerala Agricultural University College of Horticulture

\section{REHNA AUGUSTINE}

Kerala Agricultural University College of Horticulture DONALD JAMES

Kerala Agricultural University College of Horticulture

\section{Research Article}

Keywords: Basmati, BADH2, aroma, mutation, exon, fragrance

Posted Date: August 26th, 2021

DOl: https://doi.org/10.21203/rs.3.rs-827202/v1

License: (a) (i) This work is licensed under a Creative Commons Attribution 4.0 International License. Read Full License 


\section{Abstract}

The aromatic rice cultivars possess excellent aroma generally when grown in their favourable and specific environments. An early maturing selection from a Kerala aromatic local landrace with short grains, named 'Biriyanicheera', when grown in normal tropical conditions was sufficiently fragrant. The present study focused on the analysis of aroma in 'Biriyanicheera'rice genotype through molecular methods. The seeds of two aromatic rice varieties viz., Biriyanicheera and Gandhakasala (from Palakkad, Thrissur and Ernakulam districts) along with one non-aromatic rice variety Triveni (control) were used for the study. The $B A D H 2$ gene was amplified in all the three rice varieties. Upon sequencing the amplified PCR products of genomic DNA, the mutation in $B A D H 2$ gene was detected. The sequencing results of aromatic varieties revealed the presence of 8 base pair mutation in exon 7 in Biriyanicheera and Gandhakasala, whereas this mutation was absent in the non-aromatic variety Triveni. This indicated that aroma production in Biriyanicheera variety is due to similar mutation in $B A D H 2$ gene as that of the popular scented rice Basmati.

\section{Introduction}

Aromatic rice, is considered as a special group of rice due to the presence of excellent aroma and superior grain quality. India holds the pride for being the homeland for the highly popular famous nature's gift, Basmati rice. With its superior, scented, long slender grain rice, Basmati is acclaimed as the major aromatic rice genotype around the globe and fetches premium price in national and international markets. At the same time, India is the homeland for many traditional aromatic rice cultivars also, which are comparable with basmati genotypes in their aroma, making many of these unrecognized landraces as an attractive low-cost alternative to the highly priced Basmati. The short grains, low yield, and lack of prominent improvement methods have kept the non-basmati cultivars, behind in the line. However, there is an immense potential for many non-basmati genotypes to hold a major share in aromatic rice market, if these genotypes are improved with high yield and other preferred qualities (Mondal et al., 2021)

Buttery et al. (1983) was the first person to analyse the aroma of cooked rice, in which 2-acetyl-1-pyrroline (2AP) was identified as a major contributor of aroma. But some studies had revealed the presence of many other volatile compounds, other than 2-AP to be responsible for the aroma in rice grains (Jezussek et al., 2002; Sansenya et al., 2018). The aroma present in different aromatic genotypes originated from diverse places and its level of expression tends to vary with genetic as well as environmental parameters.

The genomic history of the aromatic population was unraveled from the diversity found in the unique genome-wide sativa-rufipogon data set (Civan et al., 2020). Several molecular markers had been developed to utilise the aroma trait in rice breeding programmes (Ahn et al., 1992; Garland et al., 2000; Jin et al., 2003). Among the 25 polymorphic SSR markers across 24 aromatic rice genotypes, RM527 might be the best marker for identification and diversity estimation of aromatic genotypes followed by RM1, RM22565 and RM207 markers (Kumar et al., 2018). 
The fragrance nature in rice is controlled by a recessive trait in homozygous condition, on chromosome 8 (Bradburry et al., 2005). The mutation in $B A D H 2$ gene leads to non- functional enzyme synthesis, which is responsible for aroma production.

Bradbury et al. (2005a) showed the presence of a gene having homology with a gene coding for betaine aldehyde dehydrogenase (BAD), consisting significant polymorphisms in the coding region of fragrant plants. Later the accumulation of 2-acetyl-1-pyrroline in fragrant rice was proposed to be due to the presence of mutations resulting in loss of function of the ' $f g r$ ' gene by introducing a stop codon in conserved amino acid sequence of BADs.

In Kerala, Wayanad Jeerakasala' and Wayanad Gandhakasala', have already been GI tagged and gained considerable attention in the international market for their suitability in multinational cuisines. However, these aromatic rice cultivars are found to possess higher fragrance, when grown in their own specific geographical niches, for their growth and proper expression of aroma and other unique characteristics. There has been decrease in aroma when the same cultivars were grown in regions other than their normal traditional growing regions. This posed difficulty in popularizing them in other major rice growing tracts of the country. If a genotype with good aroma that can be grown in normal tropical conditions is available, it can be introduced in other parts also. The early maturing selection from a Kerala aromatic local landrace with short grains, named 'Biriyanicheera', when grown in normal tropical conditions was observed to have sufficient aroma. It has the capacity to produce sufficient aroma wherever it is grown, irrespective of the geographical or environmental conditions. In this context, the present study focuses on the molecular analysis of aroma gene in 'Biriyanicheera' rice genotype through gene sequencing.

\section{Materials And Methods}

Rice varieties were used in this study are as detailed below :

a) Biriyanicheera - test variety (newly identified and recommended aromatic rice variety for tropical areas) for the evaluation of molecular basis of aroma.

b) Gandhakasala - standard aromatic variety (aromatic check) for comparison

c) Triveni - standard non-aromatic variety (Non-aromatic check) for comparison

d) Pusa basmati 1 - Popular aromatic rice variety for Validation of $B A D H 2$ primer

The objective of the research programme was to find out the molecular mechanism of aroma producing gene in early maturing selected line of Biriyanicheera rice. The study was carried out at the Centre of Plant Biotechnology and Molecular Biology (CPBMB), College of Horticulture, Thrissur during the period 20172019.

\subsection{Plant materials}

The aromatic rice genotypes Biriyanicheera and Gandhakasala (check genotype) grown in Mulangunnathukavu ( $10.5989^{\circ} \mathrm{N}, 76.2146^{\circ} \mathrm{E}$ and $26 \mathrm{~m}$ above MSL-) of Thrissur district, Kerala districts 
of Kerala along with a Non-aromatic genotype Triveni grown in Mulangunnathukavu from Thrissur, Kerala during the period, 2017-2018 were used for the study. The average days for maturity of rice genotypes Biriyanicheera, Gandhakasala and Triveni variety were 105, 120 and 105 days respectively. Pusa Basmati 1 , the highly popular and well studied aromatic rice variety was used for the validation of specific primers designed for $B A D H 2$ gene.

\subsection{Raising of rice plants}

Seeds of aromatic rice genotypes, Biriyanicheera and Gandhakasala and the non-aromatic rice genotype Triveni were germinated in petri plates lined with moist tissue paper and allowed to germinate. After a week, the germinated seedlings were transferred to a pot. Later, 21 days old seedling were transplanted into new pots at three seedlings per pot.

\subsection{Molecular characterization}

\subsubsection{DNA isolation}

Genomic DNA was isolated from young leaves of rice plants grown in pots. Fresh and green leaves yielded good quality of DNA in required quantity. The leaves were collected early in the morning from all the three genotypes. The collected leaves were immediately covered in aluminium foil and carried to the laboratory. The extraction of genomic DNA from the leaves was performed through CTAB method (Dellaporta et al., 1983).

\subsubsection{Quantity and quality determination of genomic DNA}

The purity of DNA was analysed using NanoDrop ND-100 spectrophotometer. Nucleic acids and proteins show absorption maxima at $260 \mathrm{~nm}$ and $280 \mathrm{~nm}$ respectively. NanoDrop recorded the absorbance at wavelengths 260 and $280 \mathrm{~nm}$ and purity was determined by the ratio OD $\left(\mathrm{A}_{260 / 280}\right)$. The OD values obtained between 1.8 and 2.0 shows the purity of the DNA, which is free from proteins. The quantity of DNA in the sample was mentioned as $\mathrm{ng} / \mu \mathrm{l}$. The quality was checked by agarose electrophoresis on 0.8 per cent agarose gel. The gel profile was examined for intactness, clarity of DNA band, the presence of contaminants such as RNA and proteins.

\subsubsection{Designing of primers for PCR}

The $B A D H 2$ gene sequence (size $=6.1 \mathrm{~Kb}$ ) retrieved from the Rice Genome Annotation Project was suitably divided into seven distinct regions based on the position of exons for convenient PCR amplification of exons. The primer details are mentioned in Table 1. 
Table 1

Details of primers synthesized from $B A D H 2$ gene sequence

\begin{tabular}{|lllll|}
\hline Primer & Forward primer sequence & Reverse primer sequence & $\begin{array}{l}\text { PCR } \\
\text { Product } \\
\text { Nongth } \\
\text { (bp) }\end{array}$ & $\begin{array}{c}\text { Exons } \\
\text { covered }\end{array}$ \\
\hline 1 & CACTCCACACCTGACACCAC & CTGCCAACTAACGAAGCACA & 980 & $1 \& 2$ \\
\hline 2 & AGCAGCATGGGACATGGTAT & ACCGGGACAGAACAAATGAG & 741 & 4 \\
\hline 3 & GCTTTCAGCTTCTTGCTCCT & GGTCACCGGAAAGCACAG & 1002 & 10,11 \\
\hline 4 & TTGGCCAACGATACTCAGTG & ATGCACAAATTGTCGCGTAA & 944 & 13,14 \\
\hline 5 & CAGTGACCAGTGCACACTTT & ACCCAACTACACCGATAGGC & 509 & 3 \\
\hline 6 & CCTCTCCTCCGTGTTAATGC & GGTCTAGCATCCAGCTCAG & 1093 & $5,6,7 \&$ \\
\hline 7 & GTGGCAAGGAAGGCAGTTA & GGTCAGGAGCAAGAAGCTGA & 707 & 9 \\
\hline 1 & ACAGAACAGAGCACTCCCTCTC & CCAGATACACAATCAGCCATGC & 846 & $1 \% 2$ \\
\hline (modified) & & & & \\
\hline
\end{tabular}

\subsubsection{Polymerase Chain Reaction (PCR)}

The total volume of the PCR reaction was $10 \mu$ constituted of Taq assay buffer, dNTPs, forward and reverse primers, Taq DNA polymerase, template DNA and sterile distilled water. The amplification profile was as follows:

The initial denaturation was carried out at $95^{\circ} \mathrm{C}$ for 3 minutes (min). The denaturation $\left(94^{\circ} \mathrm{C}\right.$ for $\left.50 \mathrm{sec}\right)$, primer annealing (around $57^{\circ} \mathrm{C}$ for $30 \mathrm{sec}$ ) and extension $\left(72^{\circ} \mathrm{C}\right.$ for $1 \mathrm{~min}$ ), were carried out for 35 times. Final extension was carried out at $72{ }^{\circ} \mathrm{C}$ for $10 \mathrm{~min}$.

\subsubsection{PCR protocol using Dimethyl Sulphoxide (DMSO):}

The total PCR reaction volume was $50 \mu \mathrm{l}$. Three per cent of DMSO (1.5 $\mu \mathrm{l}$ for $50 \mu \mathrm{l}$ reaction) was used for the amplification in addition to Taq assay buffer, dNTPs, forward and reverse primers, Taq DNA polymerase, template DNA and sterile distilled water. The initial denaturation was carried out at $95^{\circ} \mathrm{C}$ temperature for $8 \mathrm{~min}$. The denaturation $\left(94^{\circ} \mathrm{C}\right.$ for $3 \mathrm{~min}$ ), primer annealing (around $55^{\circ} \mathrm{C}$ for $30 \mathrm{sec}$ ) and extension $\left(72^{\circ} \mathrm{C}\right.$ for $1 \mathrm{~min}$ ) steps were repeated for 35 times. The quality of the amplified PCR product was checked on 1.2 per cent agarose gel by agarose gel electrophoresis. The amplified PCR products were sequenced at AgriGenome Labs Pvt. Ltd., Kochi, Kerala.

\subsubsection{Analysis of sequence data}


The forward and reverse DNA sequences obtained from sequencing results were used to construct contigs using CAP3 software. The contigs were then aligned with the reference $B A D H 2$ sequence retrieved from the Rice Genome Annotation Project using CLUSTAL OMEGA software to analyze the possible mutations in the exonic regions of genomic DNA.

\subsubsection{Validation of specific primers of BADH2 gene :}

The specific primers designed for $B A D H 2$ gene were evaluated for region 1 covering the exons 1 and 2 in the three aromatic rice genotypes Biriyanicheera, Gandhakasala and Pusa Basmati 1 along with the nonaromatic rice genotype Triveni. The genomic DNA was used for the amplification of PCR products.

\section{Results}

\subsection{Molecular characterization 3.1.1 DNA isolation and PCR}

Fresh and young leaves of Biriyanicheera, Gandhakasala, and Triveni collected during early morning hours were used for DNA isolation. The quality of DNA was assessed using agarose gel electrophoresis. Single intact band of good intensity was obtained indicated that the isolated DNA was of good quality. The DNA was free from RNA and protein contamination. The concentration of the DNA was between 300 and 800 $\mathrm{ng} / \mu \mathrm{l}$. The A260/A280 ranged between 1.8 and 2.0 indicating good quality of genomic DNA.

PCR reaction was performed using the seven different primers amplifying the regions in genomic DNA containing the exons. The annealing temperatures for the primers ranged between $55^{\circ} \mathrm{C}$ and $60^{\circ} \mathrm{C}$. The PCR products were electrophoresed on a 1.2 per cent agarose gel. The required specified bands were observed (Plate 1).

There was no amplification for primer 1 designed for amplifying exons 1 and 2 . The amplification of the above region was attempted in different annealing temperatures of range $55^{\circ} \mathrm{C}$ to $65^{\circ} \mathrm{C}$. Since there was no amplification of DNA with the specified primer, a new set of primer was designed to amplify the genomic DNA (exons 1 and 2). The new set of primer is mentioned below.

Forward primer: 5' ACAGAACAGAGCACTCCCTCTC 3'

Reverse primer: 5' CCAGATACACAATCAGCCATGC 3'

The PCR reaction performed with the new set of primers showed no amplification. The product amplification was attempted with certain modifications including, altered primer concentration, change of PCR buffer etc. PCR reaction of Triveni genotype produced a non- specific amplification, whereas the genotypes Biriyanicheera and Gandhakasala showed no bands in agarose gel. The reason for nonamplification was assumed to be due to the presence of GC rich regions in the genomic DNA sequence lying between exons 1 and 2 . So a modified PCR reaction was performed with 3 per cent Dimethyl 
Sulphoxide (DMSO). The use of DMSO in PCR amplified the genomic DNA in Triveni (non-aromatic) (Plate 2) whereas no amplification was seen in Biriyanicheera and Gandhakasala.

\subsubsection{PCR reaction using Phusion enzyme (High fidelity DNA polymerase)}

High fidelity DNA polymerase enzyme (Phusion), capable of amplifying GC rich genomic regions, was used to amplify the exons 1 and 2 . The agarose gel separation showed the presence of desired band size in Triveni genotype, whereas non-specific amplification was observed in both Biriyanicheera and Gandhakasala genotypes (Plate 3). The secondary amplification of the PCR products showed non-specific amplification (Plate 4).

\subsection{Sequencing of $B A D H 2$ gene}

The DNA sequence of $B A D H 2$ gene of genotypes Biriyanicheera, Gandhakasala and Triveni obtained by sequencing were used to generate the contigs by using CAP3 software. The $B A D H 2$ gene sequence of the rice genotypes was submitted to NCBI Gen bank.

$B A D H 2$ gene in Biriyanicheera rice genotype Accession number: MN337026

$B A D H 2$ gene in Gandhakasala rice genotype Accession number: MN337027

\subsection{Analysis of sequence data}

The genomic DNA sequence of $B A D H 2$ gene present in all genotypes was aligned by Multiple Sequence Alignment (MSA) by using CLUSTAL OMEGA software. The reference sequence, Locus Id:

LOC_Os08g32870, obtained from Rice Genome Annotation Project, was used for the comparison of sequences. MSA identified the presence of 8 base pair mutation and 3 SNPs in the exon 7 of both the genotypes Biriyanicheera and Gandhakasala. The mutation was absent in non-aromatic genotype Triveni. The sequences were further compared with the reported exon 7 sequence of Basmati genotype available in NCBI. The MSA showed that mutation in both Biriyanicheera and Gandhakasala were similar to the reported mutation in Basmati cultivars as mentioned Table 2.

Table 2

Sequences of exon 7 mutation in aromatic and non aromatic rice varieties 


\section{Exon 7 mutation}

Reference seg

Basmati

Triveni

Biriyanicheera

Gandhakasala
GGTAAAAAGATTATGGCTTCAGCTGCTCCTATGGTTAAGGTTTGTTTCCAAATTTCTGTG

GGTATAT------ ATTTCAGCTGCTCCTATGGTTAAGGTTTGTTTCCAAATTTCTGTG

GGTAAAAAGATTATGGCTTCAGCTGCTCCTATGGTTAAGGTTTGTTTCCAAATTTCTGTG

GGTATAT------ ATTTCAGCTGCTCCTATGGTTAAGGTTTGTTTCCAAATTTCTGTG

GGTATAT------ АTTTCAGCTGCTCCTATGGTTAAGGTTTGTTTCCAAATTTCTGTG

$\star \star \star \star *$

Reference seq - Reference sequence

Basmati - aromatic rice variety

Triveni - Non aromatic rice variety

Biriyanicheera - aromatic rice variety

Gandhakasala - aromatic rice variety

\subsection{Validation of specific primers of $B A D H 2$ gene}

The specific primers designed for region 1 covering the exons 1 and 2 of $B A D H 2$ gene was used for the amplification of genomic DNA. The amplification was successful only in non-aromatic genotype Triveni, whereas aromatic genotypes Biriyanicheera, Gandhakasala and Pusa basmati 1 showed no amplification (Plate 5). The primer 1 produced PCR band with desired band size of $846 \mathrm{bp}$ in Triveni genotype.

\section{Discussion}

The aromatic rice varieties, 'Basmati' (popular around the globe) and 'Gandhakasala' (popular in Kerala, India) are having GI tags, indicating that for their growth and proper expression of aroma and other unique characteristics, they need their own specific geographical niches. Whereas, the test variety is having the capacity produce sufficient aroma in wherever it is grown, irrespective of the geographical or environmental conditions. Aroma detection of rice grains was performed by Sensory evaluation test by DUS (Distinctness, Uniformity, Stability) protocol prescribed by IIRR, Hyderabad. During the analysis of grains, Biriyanicheera had good to strong aroma, Gandhakasala had Medium to good aroma while Triveni had no aroma. 
The genetic basis of rice aroma trait ( $f g r$ ) explored by many researchers in early 1992 , revealed the recessive nature of the gene and it was located at $4.5 \mathrm{cM}$ distance from the marker RG28 (Ahn et al., 1992). Later, the aroma gene fgrwas located to be between markers RM223 and RM342 (Wanchana et al., 2005). The map-based cloning and sequencing of the fgr region identified significant difference in the Badh2 gene between scented and non-scented cultivars. The mutation in 7th exon of Badh2 gene, which led to loss of Badh2 protein, was thought to be controlling the aroma in rice. Similarly, the amplification of $B A D H 2$ (or $f g r$ ) gene was attempted to understand the actual molecular reasons for the special nature of Biriyanicheera genotype. The sequencing of the genomic DNA consisting of exons of $B A D H 2$ gene helped to unravel the molecular nature in Biriyanicheera. The occurrence of previously reported 8bp mutation (TATATATTT) in the exon 7 of BADH2 gene in both the Biriyanicheera and Gandhakasala genotypes suggests that the aroma gene present in them must have followed similar path of evolution and inheritance as that of Basmati cultivars. The occurrence of $8 \mathrm{bp}$ deletion in the $B A D H 2$ gene is also reported by many researchers in various rice genotypes of the world (Bradburry et al., 2005; Chen et al., 2008). The results showed negative for the occurrence of mutations in other exons of $B A D H 2$ gene, whereas there have been reports of presence of mutations in exons 1,2,10,13,14 and also regions between exon 4 and 5 (Shi et al., 2008; Amarawathi et al., 2008; Kovach et al., 2009; Shao et al., 2011).

The non-amplification of genomic DNA coding for exon 1 and 2 in both the aromatic genotypes was not clear. Two primers designed to amplify the exons along with the promoter regions were lying in different regions. The amplification of same region in Triveni genotype shows the functionality of the primers designed. Hence, the problem can be attributed to the major difference in genome sequence of the region, which makes it difficult to amplify the regions by the primers used. The molecular complexity of the above region can be solved through advanced methods like, $5^{\prime}$ - genome walking or 5 ' - RACE (Rapid Amplification of CDNA ends). The production of aroma by Biriyanicheera might not be precisely due to mutation in chromosome 8 . The presence of novel gene in other chromosomes can be a factor for the differential aroma production in the genotype. Amarawathi et al. (2008) has reported similar example about $B A D H 1$ gene present in chromosome 3 and chromosome 4 as responsible for aroma production. The $B A D H 1$ gene is involved in salt stress response in rice crop and the mechanism in unknown (Bradburry et al., 2005) Two additional genes similar to that of $B A D H$ has been reported on chromosome 7 (Chen et al., 2008). The other contradicting reports have suggested the presence of several genes determining the aroma in rice. For example, a major QTL on chromosome 8 and two minor QTL on chromosome 3 and 4 (Amaravathi et al., 2008), two recessive genes (Hien et al., 2006), one major QTL on chromosome 8 and two minor QTL on chromosome 4 and 12 (Lorieux et al., 1996) are some of the reported locations aroma trait. The primers designed for amplifying the promoter region, exons 1 and 2 was used to differentiate the aromatic and non-aromatic rice cultivars. The presence of clear band from PCR reaction of Triveni (non-aromatic) rice variety shows the usefulness of the primer as a marker for aroma. Similarly Bradburry et al. (2005b) has used allele specific primers for discriminating the aromatic rice varieties from the non-aromatic.

\section{Conclusion}


The present study indicates that aroma production in Biriyanicheera variety is due to similar mutation in $B A D H 2$ gene as that of the popular aromatic rice Basmati.

\section{Declarations}

\section{Funding information}

This work was financially supported by Department of Biotechnology (DBT), Government of India.

\section{Conflicts of interest/Competing interests:}

The authors declare that there are no conflict of interests/competing interests among them.

\section{Availability of data and material :}

Available

\section{Code of availability :}

Available

\section{Acknowledgement}

Authors are grateful to the Department of Biotechnology, Govt. of India, for providing full funding, and College of Horticulture, Vellanikkara, Kerala Agricultural University, for providing facilities, to conduct this research programme.

\section{References}

1. Ahn SN, Bollich CN, Tanksley SD (1992) RFLP tagging of a gene for aroma in rice. Theor Appl Genet 84(8):825-828. https://doi.org/10.1007/s10967-005-0586

2. Amarawathi Y, Singh R, Singh AK, Singh VP, Mohapatra T, Sharma TR, Singh NK (2008) Mapping of quantitative trait loci for basmati quality traits in rice (Oryza sativa L.). Mol Breed 21(1):49-65. https://doi.org/10.1007/s11032-007-9108-8

3. Bradbury LM, Fitzgerald TL, Henry RJ, Jin Q, Waters DL (2005a) The gene for fragrance in rice. Plant Biotechnol. J. 3(3): 363-370. https://doi.org/10.1111/j.1467-7652.2005.00131.x

4. Bradbury LM, Henry RJ, Jin Q, Reinke RF, Waters DL (2005b) A perfect marker for fragrance genotyping in rice. Mol Breed 16(4):279-283. https://doi.org/10.1007/s11032-005-0776-y 
5. Buttery RG, Ling LC, Juliano BO, Turnbaugh JG (1983) Cooked rice aroma and 2-acetyl-1-pyrroline. J Agric Food Chem 31(4):823-826. https://doi.org/10.1021/jf00118a036

6. Che S, Yang Y, Shi W, Ji Q, He F, Zhang Z, Cheng Z, Liu X, Xu M (2008) Badh2, encoding betaine aldehyde dehydrogenase, inhibits the biosynthesis of 2-acetyl-1-pyrroline, a major component in rice fragrance. Plant Cell 20(7): 1850-1861. https://doi.org/10.1105/tpc.108. 058917

7. Civan P, Ali S, Batista-Navarro R, Drosou K, Ihejieto C, Chakraborty D, Ray A, Gladieux P, Brown TA (2020) Origin of the aromatic group of cultivated rice (Oryza sativa $L$ ) traced to the Indian subcontinent. Genome Biol Evol. 11(3): 832-843. https://doi.org/10.1093/ gbe/evz039

8. Dellaporta SL, Wood L, Hicks JB (1983) A plant DNA mini preparation: version II. Plant Mol Biol Rep 1:19-21. https://doi.org/10.1007/BF02712670

9. Garland S, Lewin L, Blakeney A, Reinke R, Henry R (2000) PCR-based molecular markers for the fragrance gene in rice (Oryza sativa L.). Theor. Appl Genet 101(3):364-371. https://doi.org/10.1007/s001220051492

10. Hien NL, Yoshihashi T, Sarhadi WA, Hirata Y (2006) Sensory test for aroma and quantitative analysis of 2-acetyl-1-pyrroline in Asian aromatic rice varieties. Plant Prod Sci 9(3):294-297. https://doi.org/10.1626/pps.9.294

11. Jezussek M, Juliano BO, Schieberle P (2002) Comparison of key aroma compounds in cooked brown rice varieties based on aroma extract dilution analyses. J Agric Food Chem 50(5):1101-1105. https://doi.org/10.1021/jf0108720

12. Jin Q, Waters D, Cordeiro GM, Henry RJ, Reinke RF (2003) A single nucleotide polymorphism (SNP) marker linked to the fragrance gene in rice (Oryza sativa L.). Plant Sci 165(2):359-364. https://doi.org/10.1016/S0168-9452(03)00195-X

13. Kovach MJ, Calingacion MN, Fitzgerald MA, McCouch SR (2009) The origin and evolution of fragrance in rice (Oryza sativa L.). Proc. Nat. Acad. Sci. USA. 106 (34): 14444-14449. https://doi.org/10.1073/pnas.0904077106

14. Kumar V, Rastogi NK, Saxena RR, Mandal SN (2018) Molecular characterization and genetic diversity analysis of aromatic rice (Oryza sativa L.) genotypes using SSR markers. J Crop Weed 14(3):94-99. https://www.cropandweed.com/archives/2018/vol14issue3/14.3.14.pdf

15. Lorieux M, Petrov M, Huang N, Guiderdoni E, Ghesquière A (1996) Aroma in rice: genetic analysis of a quantitative trait. Theor Appl Genet 93(7): 1145-1151. https://doi.org/ 10.1007/BF00230138

16. Mondal D, Kantamraju P, Jha S, Sundarrao GS, Bhowmik A, Chakdar H, Mandal S, Sahana N, Roy B, Bhattacharya PM, Chowdhury AK, Choudhury A (2021) Evaluation of indigenous aromatic rice cultivars from sub-Himalayan Terai region of India for nutritional attributes and blast resistance. Sci Rep 11:4786. https://doi.org/10.1038/s41598-021-83921-7

17. Sansenya S, Hua Y, Chumanee S (2018) The correlation between 2-acetyl-1-pyrroline content, biological compounds and molecular characterization to the aroma intensities of Thai local rice. $J$ Oleo Sci 67(7):893-904. https://doi.org/10.5650/jos.ess17238 
18. Shao GN, Tang A, Tang SQ, Luo J, Jiao GA, Wu JL, Hu PS (2011) A new deletion mutation of fragrant gene and the development of three molecular markers for fragrance in rice. Plant Breed 130(2):172176. https://doi.org/10.1111/j.1439-0523.2009.01764.x

19. Shi W, Yang Y, Chen S, Xu M (2008) Discovery of a new fragrance allele and the development of functional markers for the breeding of fragrant rice varieties. Mol Breed 22(2):185-192. https://doi.org/10.1007/s11032-008-9165-7

20. Wanchana S, Kamolsukyunyong W, Ruengphayak S, Toojinda T, Tragoonrung S, Vanavichit A (2005) A rapid construction of a physical contig across a $4.5 \mathrm{cM}$ region for rice grain aroma facilitates marker enrichment for positional cloning. Sci Asia 31(3):299-306. https://doi.org/10.2306/scienceasia1513-1874.2005.31.299

\section{Figures}

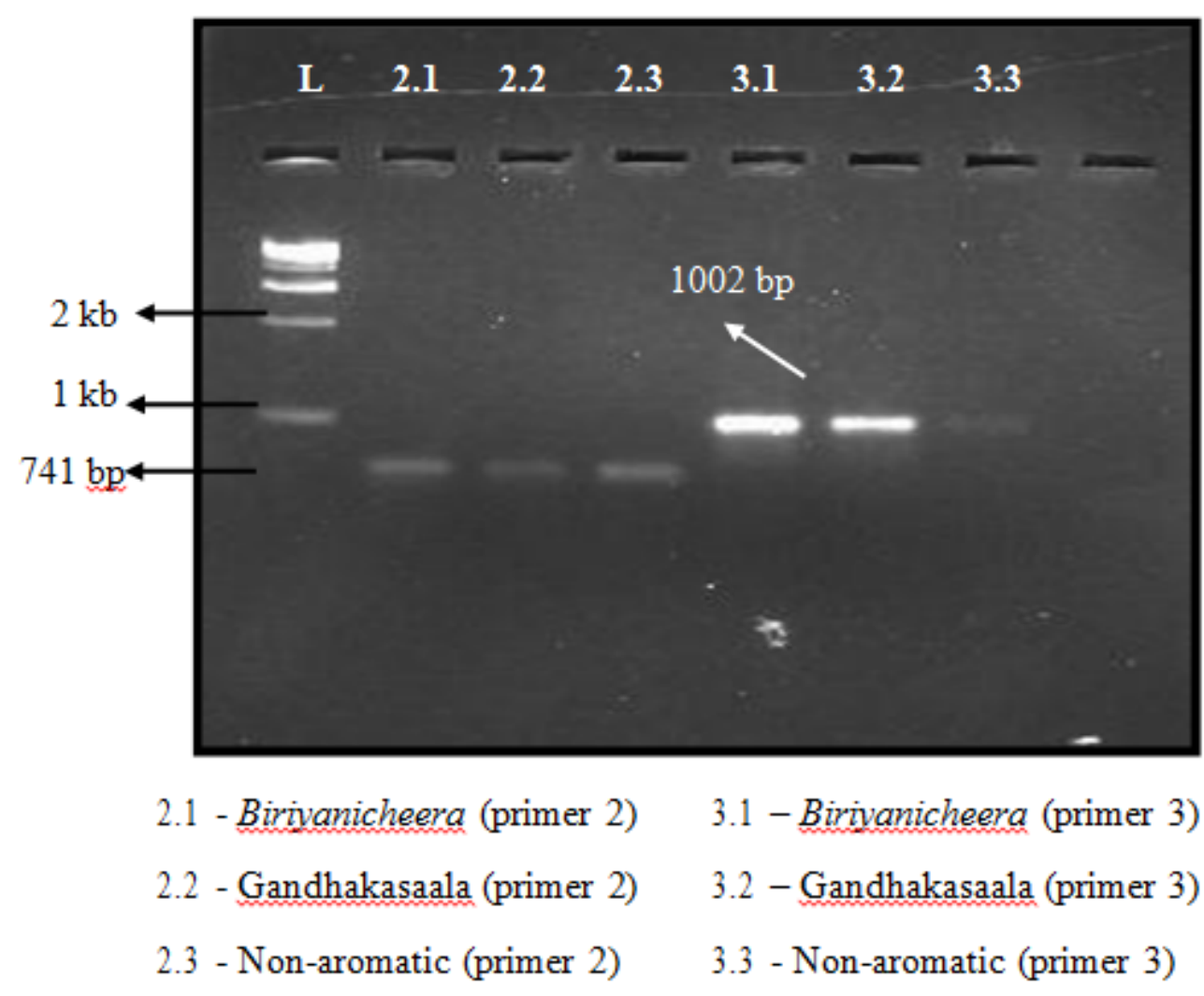

\section{Figure 1}

Plate 1A. BADH2 gene specific PCR bands L - DNA ladder 2.1 - Biriyanicheera (Primer 2) 2.2 Gandhakasaala (Primer 2) 2.3 - Non-Aromatic (Primer 2) 3.1 - Biriyanicheera (Primer 3) 3.2 Gandhakasaala (Primer 3) 3.3 - Non Aromatic (Primer 3) 


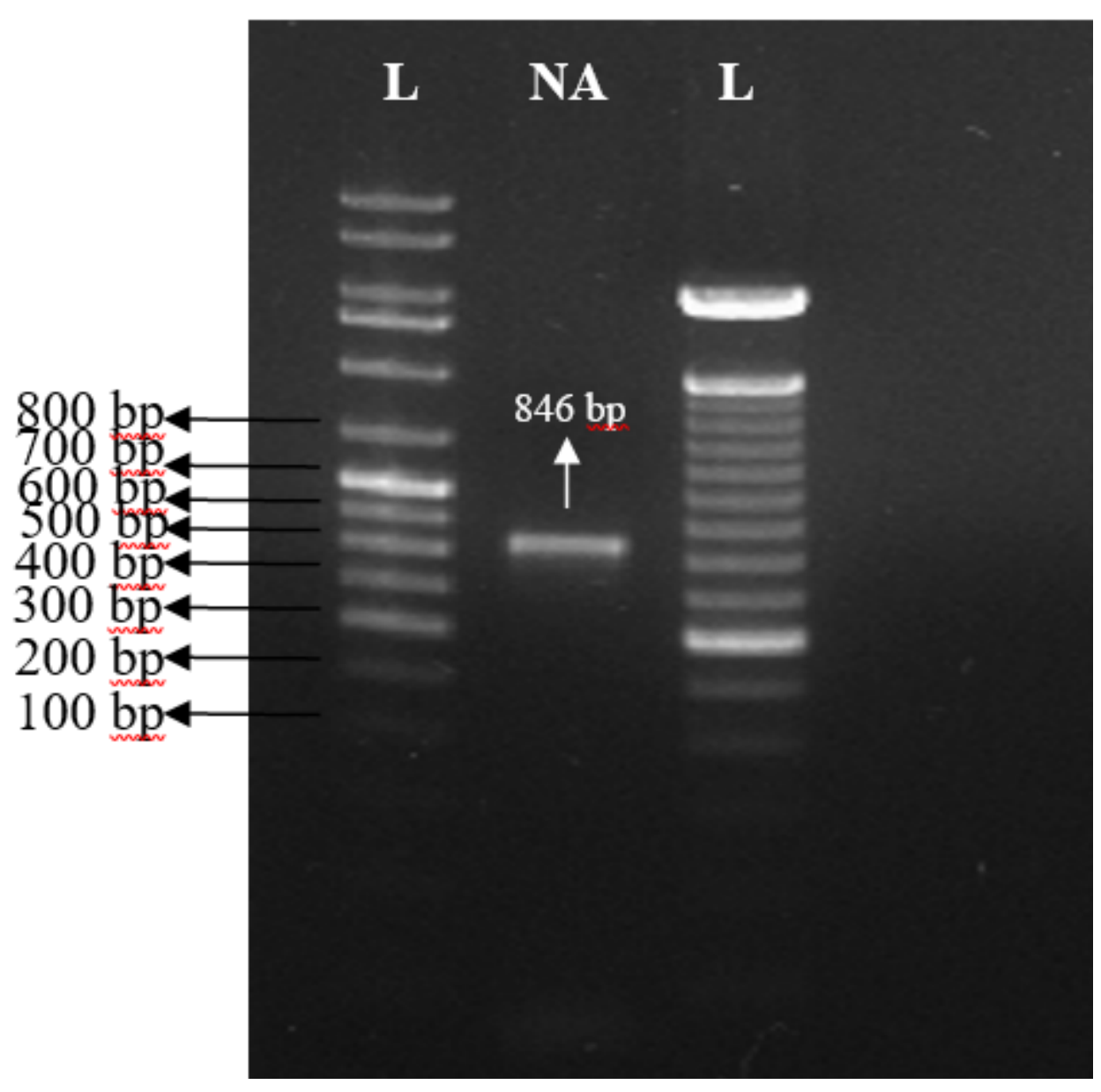

Figure 2

Plate 2 Modified PCR (DMSO) for Triveni rice variety 


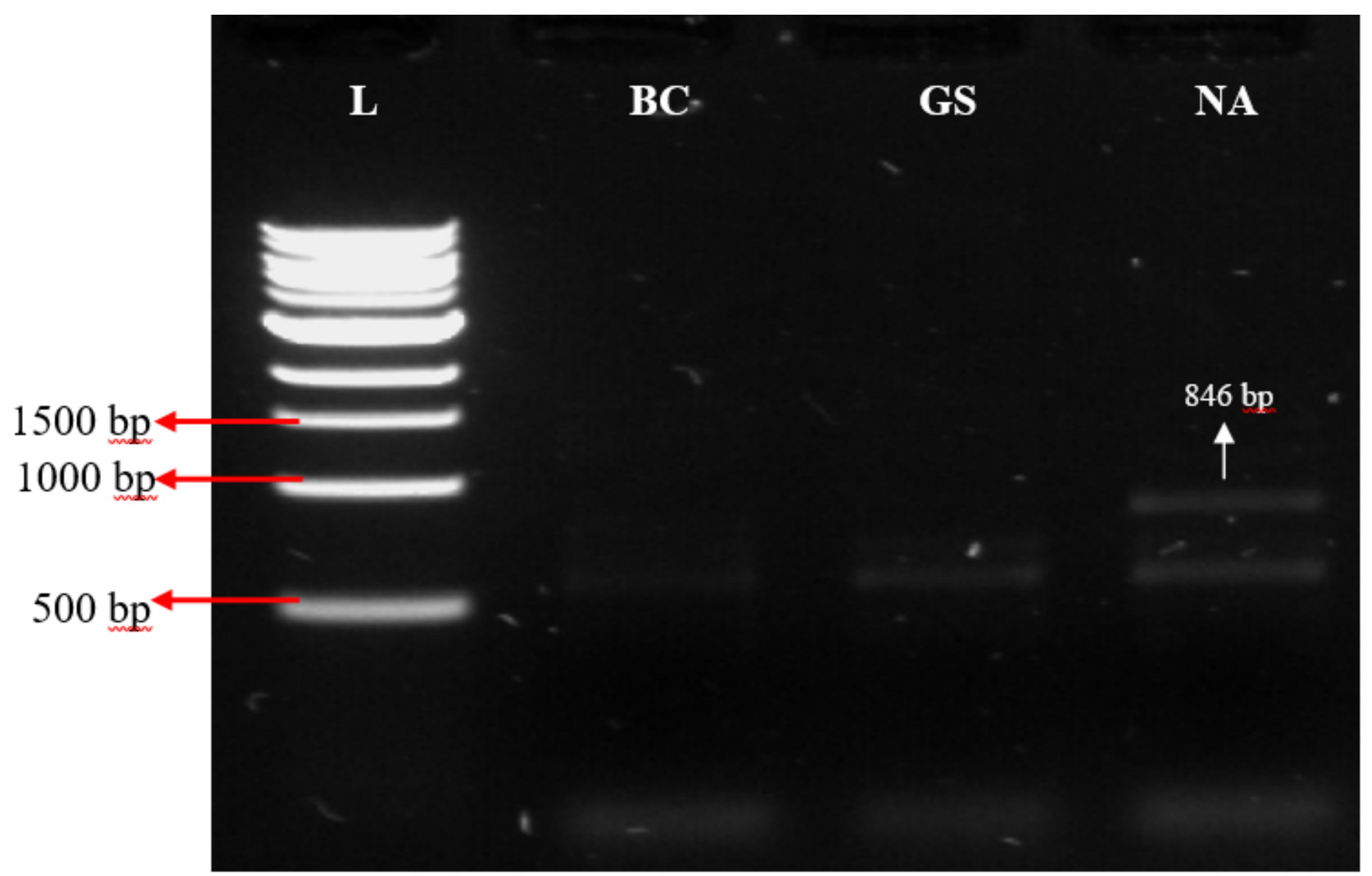

\section{Figure 3}

Plate 3. PCR amplification using Phusion enzyme L- Ladder BC- Biriyanicheera GS- Gandhakasala NATriveni (Non aromatic)

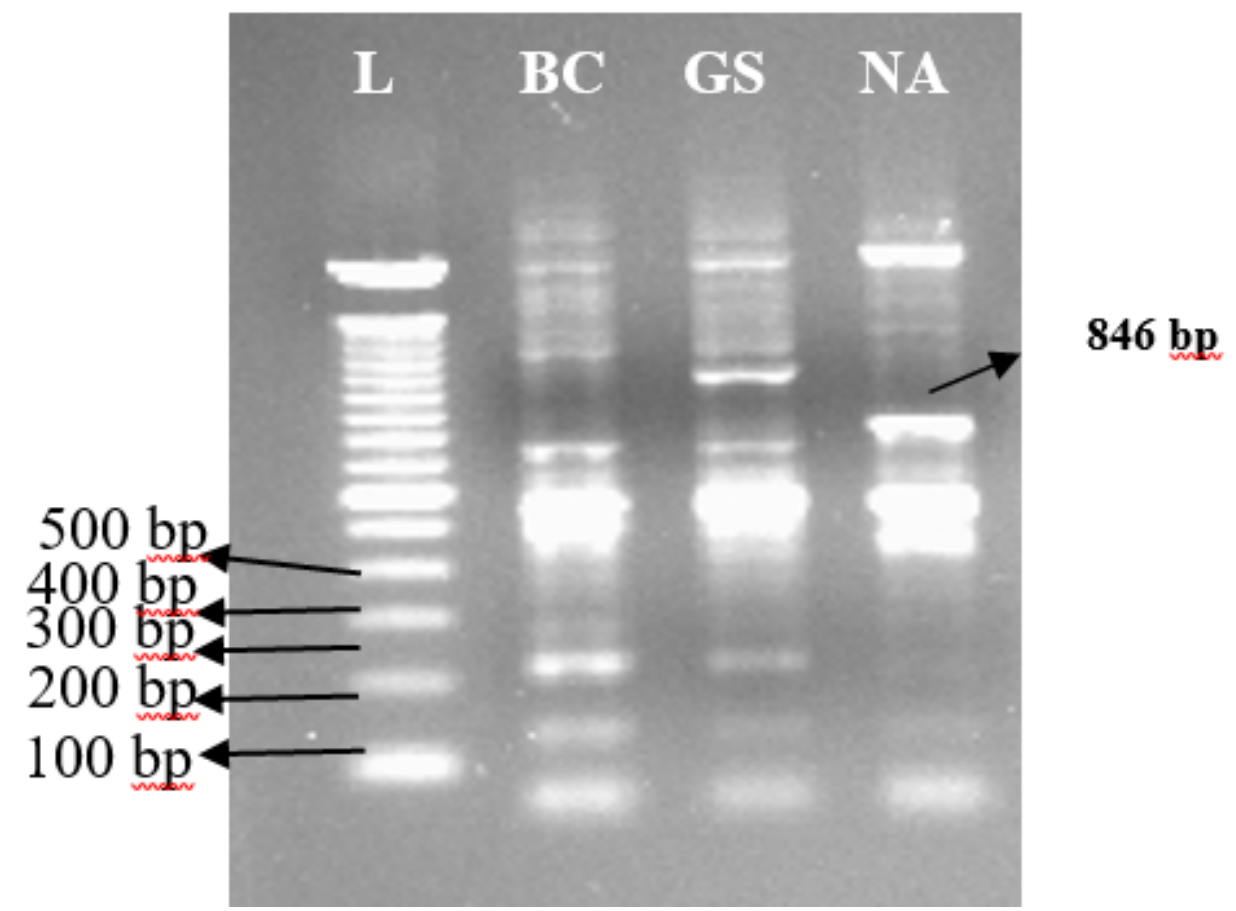




\section{Figure 4}

Plate 4. Secondary PCR amplification of PCR products produced by Phusion enzyme L- Ladder BCBiriyanicheera GS- Gandhakasala NA-Triveni (Non aromatic)

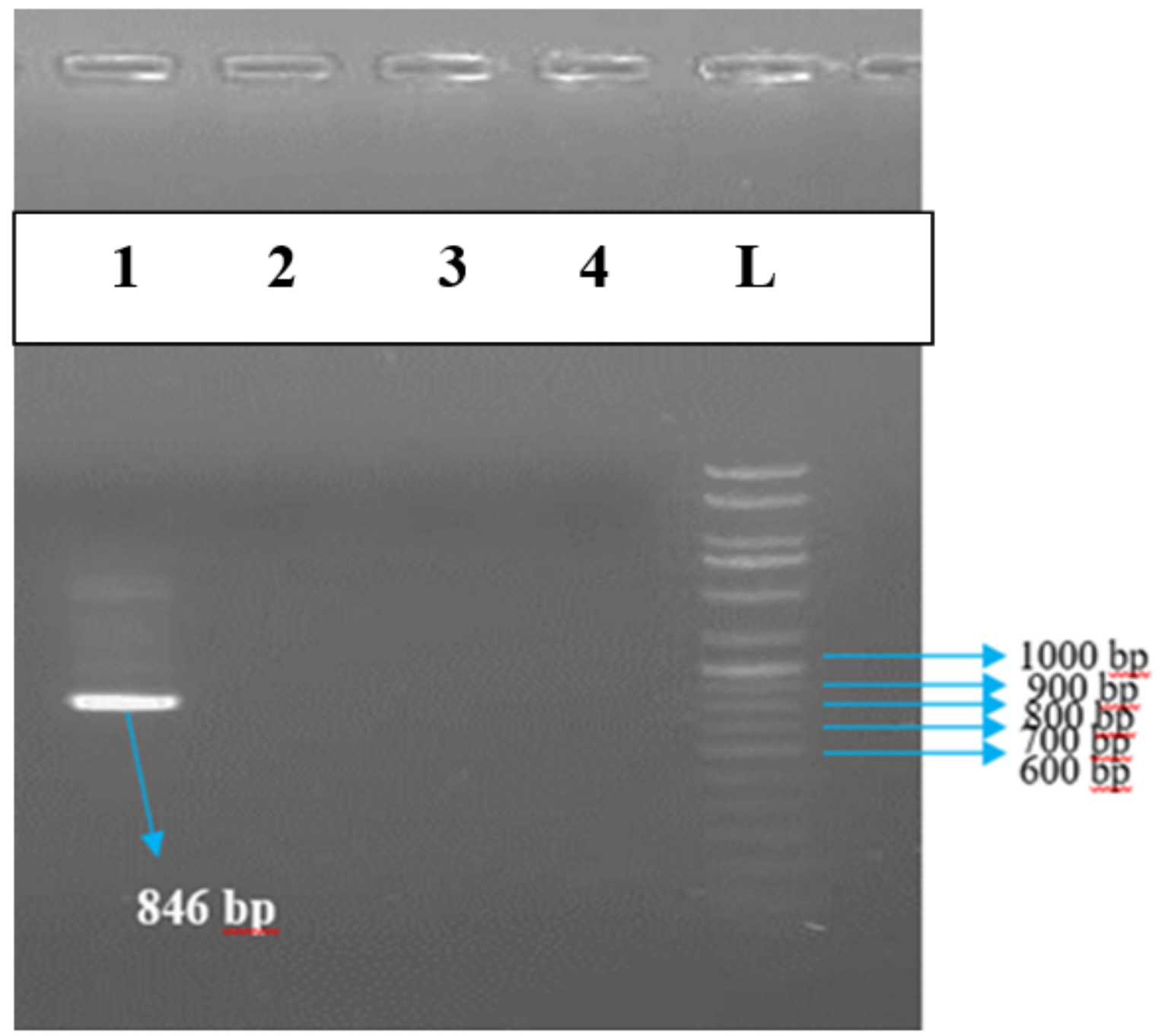

Figure 5

Plate 5. Validation of specific primers of BADH2 gene 1 - Triveni (Non Aromatic) 2 - Biriyanicheera 3Gandhakasala 4 - Pusa Basmati $1 \mathrm{~L}$ - 100 bp ladder 